\section{Ukrainian Journal \\ of Educational Studies and Information Technology}

ISSN: 2521-1234 online

Ukr. J. of Educ. Stud. and Inf. Technol.

$8(1), 17-27$

doi: 10.32919/uesit.2020.01.02

Vol. 8, Issue 1, 2020

UDC 378.091.33-027.22:004(65)

\title{
Investigating the use of PowerPoint in teaching: a case study at Annaba Higher School of Management Sciences
}

\author{
Fethi Guerid
}

\begin{abstract}
The aim of this study is to investigate the use of PowerPoint at Annaba Higher School of Management Sciences Algeria with 2nd year Master Class students. The authors have tried to find out how PowerPoint is used and whether the students are satisfied with the way it is used at this school. The other task is to investigate to what extent the pedagogical features such as concentration, grasping and eagerness for learning are affected by the use of PowerPoint as a teaching tool.

To conduct this investigation, the questionnaire as a research tool has been used. The questionnaire is made up of three sections: personal information, the board use and PowerPoint use. The number of questions included in this questionnaire is 18. Eight questions in the section related to the board use and ten questions in the section related to PowerPoint use. The study has taken place in the first semester of the 2019/2020 academic year from October 2019 to January 2020 at Annaba Higher School of Management Sciences Algeria.

The results of this investigation have revealed that the classical way of teaching such as the use of the board instead of PowerPoint is preferred by this research population. This study has shown that the pedagogical features like motivation, concentration and grasping are higher with the modules where the teachers use the board more than with the modules where the teachers use PowerPoint as a teaching tool. The findings of the study show that the way PowerPoint is used in this school with this research population carries various drawbacks and this what might hinder educational and pedagogical success.
\end{abstract}

Keywords: higher education; PowerPoint; teaching; board; pedagogical features.

\section{INTRODUCTION}

The study aims to investigate the use of PowerPoint among master class lecturers of Annaba Higher School of Management Sciences from students' perceptions. It investigates the rate of PowerPoint use with all the modules and whether the students are satisfied with this use. This investigation tries to find out if the level of grasping and concentration of this research population are high or low when teachers use PowerPoint as a teaching tool in their interaction with students. Alternatively, this study investigates whether PowerPoint use with these students is meeting educational and pedagogical goals. 
The introduction of technology in education is taking a climbing position and the interaction between teachers and their students occurs much more with the use of new technological tools such as PowerPoint. An important number of teachers and lecturers are quitting the classical ways of teaching such as the use of black board and chalk and even the white boards and markers. We notice rather the use of PowerPoint especially in higher education as Howells (2007, p. 137) point out : "In many higher education settings, it is a rare event for a lecturer not to use PowerPoint". PowerPoint can be considered as the new "pen" of nowadays higher education lecturers. PowerPoint is widely used and every day millions of presentations are presented worldwide as Livers mentions: "without a doubt, Microsoft PowerPoint is one of the most widely used presentation graphics programs in use today. Every day, almost 30 million PowerPoint presentations are made worldwide" (2008, p. 67).

Davis declares that: "Various software programs can be used to create slides of formatted text and graphics but Microsoft's PowerPoint has so dominated the market that many people use PowerPoint as though it were a generic term" (2009, p. 453). PowerPoint has then become the software the most widely used among teachers in illustrating lectures and explaining ideas and concepts.

\section{Advantages of PowerPoint use in education}

PowerPoint is not a complicated or difficult software to use. It is rather simple and easy manipulated tool that is based on opening, adding and filling slides with information in the form of script, drawing, diagrams or graphs. Finkelstein and Samsonov state: "Microsoft Office PowerPoint is a versatile and easy to use tool that can support learning in its many phases. A teacher can add PowerPoint to their arsenal of educational technologies and enhance the classroom experience in many ways" (2007, p. 9). The teacher can henceforth use PowerPoint in the classroom to support their lecture or to clarify some ideas or aspects of the lecture in another way different from the classical ways such as the use of the black or white board.

The PowerPoint use can save time to the teacher and allows to cover a long program in a short period of time as Khirwadkar and Pushpanadham point out: "Microsoft PowerPoint presentation has a great potential to accelerate the learning process" (2005, p. 108). According to Catahan (2015) the use of PowerPoint in the classroom has become a necessary tool in giving logical information related to various concepts and ideas being clarified by the teacher to his learners.

PowerPoint offers the possibility to teachers to create presentations using animations, audio and music in ways not possible with the chalkboard. This use of PowerPoint does not require from teachers to be highly skilful in information technology or experienced as Livers declares (2008, p. 67): “Using 
the built-in wizards, even the most inexperienced PowerPoint user can create professional-looking graphics to support the learning objectives".

Therefore, PowerPoint can be considered as a modern tool in teaching that offers teachers the possibility to present their lessons and lectures in modern ways using colours, graphs and diagrams along with audio and video supports. It is, as well, a tool that allows teachers to cover long teaching programs in short time.

\section{Disadvantages of PowerPoint use in education}

In spite of the various virtues of PowerPoint use in education by teachers and lecturers, these last ones have been criticized by the overuse of this tool in teaching. In fact, the teacher is supposed to hold their students eager and motivated in the classroom by keeping their attention high. However if they overuse PowerPoint in a way that causes a loss of attention to their students, learning in this way becomes purposeless and pedagogical goals will not be achieved.

Livers points that: "overuse of this technology at the expense of good instructional content and delivery can result in "PowerPoint poisoning" (2008, p. 67). Do not expect the use of technology to make up for poor teaching. Overloading students with irritating, irrelevant, or unnecessary flashness in a presentation can result in reduced effectiveness of the lesson". Poor teaching henceforth cannot be replaced by PowerPoint presentations because this tool is only a support to teaching and lecturing and it is not the teaching in itself. If it were so, machine teaching will replace human teachers and millions of salaries will be saved. Therefore the human interaction is very important along with effective teaching based on motivating students using various ways.

Because of the overuse of PowerPoint, both teachers and learners have become addicted to it and has become like oxygen as Mortiboys points out: "Some lecturers and learners respond to the absence of PowerPoint in a session as though it was an absence of oxygen - how can it possibly go ahead? A PowerPoint dependency has sprung up" (2010, p. 80). This tendency cannot guarantee effectiveness in teaching because the risk of the absence of technology use is always possible such as the breakdown of information technology tools or electricity problems. Teachers and learners should always be effective and focused whatever is the tool used in the classroom; be it a chalkboard, a white board or a Microsoft PowerPoint presentation or any other tool.

Henceforth it can be concluded that the overuse of PowerPoint can lead to poor teaching in situations where the human interaction is low or absent and where learners are passive listeners and viewers. This overuse of PowerPoint affects negatively the eagerness and motivation of learners because their level of grasping becomes very low when there is no feedback between teachers and learners. 


\section{Time and place setting}

Ukr. J. of Educ.

Stud. and Inf.

Technol.

The study has been conducted in the first semester of the current academic year 2019/2020 from October 2019 to January 2020 at Annaba Higher School of Management Sciences Algeria.

\section{Research population}

The target population of our study are 2nd year Master's students of Annaba Higher School of Management Sciences Algeria.

\section{Research tool}

To conduct this investigation, we have used a questionnaire as a research tool. 36 copies of the questionnaire have been distributed to our research population where we have explained every question and where we have allowed them to reply using the language they master better either English, French or Arabic.

The questionnaire is made of three parts: Personal Information, Board Use and PowerPoint Use.

In Personal Information part, the participants were asked about their age and gender without being asked to mention their names and this in order to make the study academic, professional and objective.

In Board Use part, the participants were asked the following questions:

1. What are the modules where the board is mainly used in the classroom?

2. How do you appreciate your satisfaction with them: $25 \%, 50 \%, 75 \%$ or $100 \%$ ?

3. Do you find the use of the board boring?

4. Do you find the use of the board tiring?

5. Do you find the use of the board interesting?

6. What is your level of CONCENTRATION when your teacher uses the board in explaining the lesson: $25 \%, 50 \%, 75 \%$ or $100 \%$ ?

7. What is your level of GRASPING when your teacher uses the board in explaining the lesson: $25 \%, 50 \%, 75 \%$ or $100 \%$ ?

8. Do you find a difficulty when reading from the board: Yes or NO? Justify if yes.

In PowerPoint Use part, the participants were asked these questions:

1. What are the modules where PowerPoint is mainly used in the classroom?

2. How do you appreciate your satisfaction with them: $25 \%, 50 \%, 75 \%$ or $100 \%$ ?

3. Do you find the use of the PowerPoint boring?

4. Do you find the use of the PowerPoint tiring?

5. Do you find the use of the PowerPoint interesting? 
6. What is your level of CONCENTRATION when your teacher uses PowerPoint in explaining the lesson: $25 \%, 50 \%, 75 \%$ or $100 \%$ ?

7. What is your level of GRASPING when your teacher uses PowerPoint in explaining the lesson: $25 \%, 50 \%, 75 \%$ or $100 \%$ ?

8. Do you find a difficulty when reading PowerPoint presentations: Yes or Ukr. J. of Educ. Stud. and Inf. Technol. 2020, 8(1) No? Justify if yes.

9. Are you satisfied with the non-use of PowerPoint in Coaching and Team Building module?

10. Do want this module to be taught using PowerPoint: Yes or No? Justify.

\section{RESEARCH RESULTS}

\section{Section A. Personal Information}

Age of the participants: it ranges between 20 and 23 years old.

Gender: 10 male participants (28\%); 26 female participants (72 \%).

\section{Section B. Board Use}

Q1: What are the modules where the board is mainly used in the classroom?

Reply: Coaching \& Team Building and Public Policies.

Q2: How do you appreciate your satisfaction with them? Are you 25\% satisfied or $50 \%, 75 \%$ or $100 \%$ ?

Results are presented in Table 1.

Table 1. Results of Q2 of B questionnaire section

\begin{tabular}{lccccc}
\hline & $25 \%$ & $50 \%$ & $75 \%$ & $100 \%$ & Total \\
\hline $\begin{array}{l}\text { Number of } \\
\text { participants }\end{array}$ & 1 & 6 & 13 & 16 & 36 \\
Percentage & $3 \%$ & $17 \%$ & $36 \%$ & $44 \%$ & 100 \\
\hline
\end{tabular}

Participants' answers on questions 3, 4, 5 and 8 about their feelings and difficulties when using the board are presented in Table 2 .

Table 2. Results of Qs 3, 4, 5 and 8 of B questionnaire section

\begin{tabular}{lccccc}
\multicolumn{1}{c}{ Question } & $\begin{array}{c}\text { Number of } \\
\text { participants }\end{array}$ & persons & percentage & persons & percentage \\
\hline $\begin{array}{l}\text { Q3: Do you find the use of } \\
\text { board boring? }\end{array}$ & 36 & 3 & $8 \%$ & 33 & $92 \%$ \\
$\begin{array}{l}\text { Q4: Do you find the use of } \\
\text { the board tiring? }\end{array}$ & 36 & 4 & $11 \%$ & 32 & $89 \%$ \\
$\begin{array}{l}\text { Q5: Do you find the use of } \\
\text { the board interesting? }\end{array}$ & 36 & 34 & $94 \%$ & 2 & $6 \%$ \\
$\begin{array}{l}\text { Q8: Do you find } \\
\text { difficulties when reading } \\
\text { from the board? }\end{array}$ & 36 & 3 & $8 \%$ & 33 & $92 \%$ \\
\hline
\end{tabular}


The main difficulties (Q8) were pointed out such as "I do not see very well", "I have a sight shortness", "I have a difficulty with the writing line of the teacher".

Participants' answers on questions 6 and 7 about their cognitive processes when using the board are presented in Table 3.

Ukr. J. of Educ.

Stud. and Inf.

Technol.

2020, 8(1)

Table 3. Results of Qs 6 and 7 of B questionnaire section

\begin{tabular}{|c|c|c|c|c|c|c|}
\hline & $25 \%$ & $50 \%$ & $75 \%$ & $100 \%$ & No reply & Total \\
\hline \multicolumn{7}{|c|}{$\begin{array}{l}\text { Q6: What is your level of concentration when your teacher uses the board in } \\
\text { explaining the lesson? }\end{array}$} \\
\hline $\begin{array}{l}\text { Number of } \\
\text { participants }\end{array}$ & 0 & 3 & 28 & 5 & 0 & 36 \\
\hline Percentage & $0 \%$ & $8 \%$ & $78 \%$ & $14 \%$ & $0 \%$ & $100 \%$ \\
\hline \multicolumn{7}{|c|}{$\begin{array}{c}\text { Q7: What is your level of grasping when your teacher uses the board in explaining } \\
\text { the lesson? }\end{array}$} \\
\hline $\begin{array}{l}\text { Number of } \\
\text { participants }\end{array}$ & 1 & 7 & 19 & 5 & 4 & 36 \\
\hline Percentage & $3 \%$ & $19 \%$ & $53 \%$ & $14 \%$ & $11 \%$ & $100 \%$ \\
\hline
\end{tabular}

\section{Section C. PowerPoint Use}

Q1: What are the modules where PowerPoint is mainly used in the classroom?

Reply: Information \& Communication Technology, Benchmarking, Research Methodology, Economic Intelligence and Strategic Management.

Q2: How do you appreciate your satisfaction with them? Are you 25\% satisfied or $50 \%, 75 \%$ or $100 \%$ ?

Results are presented in Table 4.

Table 4. Results of $\mathbf{Q} 2$ of C questionnaire section

\begin{tabular}{lcccccc}
\hline & $25 \%$ & $50 \%$ & $75 \%$ & $100 \%$ & No reply & Total \\
\hline $\begin{array}{l}\text { Number of } \\
\text { participants }\end{array}$ & 11 & 19 & 3 & 0 & 3 & 36 \\
Percentage & $31 \%$ & $53 \%$ & $8 \%$ & $0 \%$ & $8 \%$ & 100 \\
\hline
\end{tabular}

Participants' answers on questions 3, 4, 5 and 8 about their feelings and difficulties when using the board are presented in Table 5 .

Table 5. Results of Qs 3, 4, 5 and 8 of C questionnaire section

\begin{tabular}{lccccc}
\hline \multicolumn{1}{c}{ Question } & Number of & \multicolumn{2}{c}{ Yes } & \multicolumn{2}{c}{ No } \\
& participants & persons & percentage & persons & percentage \\
\hline $\begin{array}{l}\text { Q3: Do you find the use of } \\
\text { PowerPoint boring? }\end{array}$ & 36 & 32 & $88 \%$ & 4 & $12 \%$ \\
$\begin{array}{l}\text { Q4: Do you find the use of } \\
\text { PowerPoint tiring? }\end{array}$ & 36 & 22 & $61 \%$ & 14 & $39 \%$
\end{tabular}




\begin{tabular}{lccccc}
\hline \multicolumn{1}{c}{ Question } & $\begin{array}{c}\text { Number of } \\
\text { participants }\end{array}$ & \multicolumn{2}{c}{ persons } & \multicolumn{2}{c}{ porcentage } \\
& persons & percentage \\
\hline $\begin{array}{l}\text { Q5: Do you find the use of } \\
\text { PowerPoint interesting? }\end{array}$ & 36 & 12 & $34 \%$ & 24 & $66 \%$ \\
$\begin{array}{l}\text { Q8: Do you find } \\
\text { difficulties when reading }\end{array}$ & 36 & 12 & $34 \%$ & 24 & $66 \%$ \\
$\begin{array}{l}\text { PowerPoint } \\
\text { presentations? }\end{array}$ & & & & & \\
\hline
\end{tabular}

Ukr. J. of Educ.

Stud. and Inf.

Technol.

2020, 8(1)

The main difficulties (Q8) were pointed out such as "Eyes problem", " Long sentences", "No movement", "No discussion", "Difficult terms", "A lot of pages", "A lot of information", "Tiring and no grasping".

Participants' answers on questions 6 and 7 about their cognitive processes when using the board are presented in Table 6.

Table 6. Results of Qs 6 and 7 of C questionnaire section

\begin{tabular}{|c|c|c|c|c|c|c|}
\hline & $25 \%$ & $50 \%$ & $75 \%$ & $100 \%$ & No reply & Total \\
\hline \multicolumn{7}{|c|}{$\begin{array}{l}\text { Q6: What is your level of concentration when your teacher uses PowerPoint in } \\
\text { explaining the lesson? }\end{array}$} \\
\hline $\begin{array}{l}\text { Number of } \\
\text { participants }\end{array}$ & 14 & 18 & 0 & 2 & 2 & 36 \\
\hline Percentage & $38 \%$ & $50 \%$ & $0 \%$ & $6 \%$ & $6 \%$ & $100 \%$ \\
\hline \multicolumn{7}{|c|}{$\begin{array}{c}\text { Q7: What is your level of grasping when your teacher uses PowerPoint in explaining } \\
\text { the lesson? }\end{array}$} \\
\hline $\begin{array}{l}\text { Number of } \\
\text { participants }\end{array}$ & 15 & 18 & 2 & 1 & 0 & 36 \\
\hline Percentage & $41 \%$ & $50 \%$ & $6 \%$ & $3 \%$ & $0 \%$ & $100 \%$ \\
\hline
\end{tabular}

Participants' answers on questions 9 and 10 about teaching Coaching and Team Building Module using Board or PowerPoint are presented in Table 7.

Table 7. Results of Qs 9 and 10 of $\mathbf{C}$ questionnaire section

\begin{tabular}{|c|c|c|c|c|c|}
\hline \multirow[t]{2}{*}{ Question } & \multirow{2}{*}{$\begin{array}{l}\text { Number of } \\
\text { participants }\end{array}$} & \multicolumn{2}{|c|}{ Yes } & \multicolumn{2}{|c|}{ No } \\
\hline & & $\begin{array}{c}\text { perso } \\
\text { ns }\end{array}$ & $\begin{array}{l}\text { percenta } \\
\text { ge }\end{array}$ & $\begin{array}{c}\text { perso } \\
\text { ns }\end{array}$ & $\begin{array}{l}\text { percenta } \\
\text { ge }\end{array}$ \\
\hline $\begin{array}{l}\text { Q9: Are you satisfied with the non- } \\
\text { use of PowerPoint in Coaching and } \\
\text { Team Building Module (the module } \\
\text { taught by the researcher who is } \\
\text { conducting this study)? }\end{array}$ & 36 & 30 & $83 \%$ & 6 & $17 \%$ \\
\hline $\begin{array}{l}\text { Q10: Do you want this module } \\
\text { (Coaching and Team Building) to be } \\
\text { taught using PowerPoint? }\end{array}$ & 36 & 2 & $6 \%$ & 34 & $94 \%$ \\
\hline
\end{tabular}

Participants pointed out some reasons of using PowerPoint for teaching Coaching and Team Building Module (Q10), namely "We want the use of some 
videos", "Just for the sake of changing the way of learning". However, 94\% participants were against using PowerPoint for teaching Coaching and Team Building Module. Their reasons were: "I like the way of explaining lessons", "I am happy with this method", " I understand well and I enjoy the way of teaching", "If PowerPoint is used it will be boring and I will not grasp", "If PowerPoint is used I will not be able to concentrate", "Reading from power point is not interesting", "With PowerPoint the teacher talks too much", "We learn better and more with the board", "We concentrate because the teacher writes on the board what he says", "We participate with the teacher".

\section{DISCUSSION OF RESULTS}

Out of seven modules, five modules are taught using PowerPoint and only two modules are taught classically using the white board. However, this wide use of PowerPoint is conflicting with pedagogical goals. According to the findings of this investigation, the use of PowerPoint is not highly appreciated by the research population who still prefer the classical way of learning when the teacher uses the board in explaining lessons.

$44 \%$ of our research population are $100 \%$ satisfied with the use board by their teachers in explaining lessons and only 3\% are $25 \%$ satisfied (see Table 1). This might indicate that there is no need expressed by our research population for the use of PowerPoint which might be the choice of teachers only.

92\% of the participants do not find the use of board as boring (see Table 2). This shows their appreciation to the use board by their teachers.

$89 \%$ do not find the use of the board as tiring (see Table 2). This is a further indication to their satisfaction with the use of board by their teachers.

94\% of the participants find the use of board interesting (see Table 2). This leads to their motivation inside the classroom.

As far as their concentration in the classroom is concerned, $78 \%$ of the participants $75 \%$ are concentrated which can be considered a high level of concentration (see Table 3).

As for their grasping when their teachers use the board in explaining the lesson, $53 \%$ of them are $75 \%$ grasping, $19 \%$ are $50 \%$ grasping and $14 \%$ are $100 \%$ (see Table 3). These rates are highly acceptable and show positive signs in the way of meeting pedagogical goals.

The results of the study unveil that $92 \%$ of the research population do not find difficulties when reading from the board and only $8 \%$ find difficulties and this because of sight shortness and because of the writing lines of teachers (see Table 2).

Therefore, we can say that the results and rates of the different aspects linked to the use board in the classroom can be considered positive and matching pedagogical goals. 
Nevertheless, the results of the study related to the different features related to the use of PowerPoint in teaching can be viewed as negative signs that may hinder achieving pedagogical goals. The following findings confirm this:

$53 \%$ of the participants are only $50 \%$ satisfied with the use of PowerPoint. Only $8 \%$ of them are $75 \%$ satisfied and $0 \%$ are $100 \%$ satisfied (see Table 4 ). This rate of satisfaction with the use of PowerPoint is low compared to the satisfaction with the use of board.

$88 \%$ of the participants find the use PowerPoint boring (see Table 5). When students feel bored their eagerness for learning will go down.

$61 \%$ find the use of PowerPoint tiring (see Table 5). This feeling will not motivate them to follow and grasp what the teacher is saying.

The results of the study show that $66 \%$ of the research population do not find the use of PowerPoint interesting. Only 34\% find the opposite (see Table 5). This lack of interest can be considered a big threat to reaching teaching goals.

As for their concentration when their teachers use PowerPoint in explaining the lesson, $50 \%$ of the participants $50 \%$ concentrate and $38 \%$ concentrate only $25 \%$ (see Table 6). This concentration is low compared to the one when their teachers use the board in explaining the lessons. This lack of concentration will not help students in understanding lessons.

The results of the study reveal that the level of grasping of the research population when their teachers use PowerPoint in explaining the lesson is low. Only $3 \%$ grasp $100 \%$ of what the teachers say inside the classroom and also only $6 \%$ grasp $75 \%$ of the lessons (see Table 6 ).

As for the difficulties that the research population encounter when reading PowerPoint presentations, 34\% suffer from eyes problem, long sentences, no movement, no discussion, difficult terms and a lot of pages and information. Whereas $66 \%$ of the participants have not claimed any difficulty (see Table 5).

As far as the satisfaction of the research population with the non-use of PowerPoint in Coaching and Team Building Module is concerned, $83 \%$ are satisfied and only $17 \%$ are not satisfied (see Table 7).

The results of the investigation show that $94 \%$ of the participants do not want the module of coaching and team building to be taught using PowerPoint because of many reasons (see results) such as their happiness with the way of explaining lessons, their rejection to PowerPoint, and their concentration and grasping when the teacher uses the board. However $6 \%$ of the research population want the Coaching and Team Building module to be taught using PowerPoint and this because they want to see some videos and they want a change in the way of teaching(see Table 7).

Consequently and unlike the results of the use of board in teaching, the use of PowerPoint results are not positive. The different pedagogical implications such as concentration, satisfaction and grasping appear in a low level. This can be considered as a danger and threat in front of meeting learners' pedagogical needs and goals. 
As a conclusion, we can say that the tendency of technology integration in education is taking a climbing position. The PowerPoint use in classroom is an example of this technology. Teachers nowadays seem to be illiterate if they do not use technology in their interaction with their learners.

Our investigation has revealed that most teachers of master classes use PowerPoint in teaching. However, this wide use cannot be considered as a positive back up to achieving pedagogical goals. According to the findings of the study, the way PowerPoint is used in this school with this research population carries various drawbacks.

This wide use of PowerPoint may hinder educational and pedagogical success because the pedagogical features have proven to be low. Concentration is higher with the use of board more than with the use of PowerPoint. This affects their grasping of lessons where the results show that the participants grasp well when their teachers use the board and not PowerPoint. Besides concentration and grasping, the results of the study have revealed that the use PowerPoint is tiring and not interesting. This causes a feeling of demotivation and loss of eagerness to learning.

Henceforth, this case of study has shown that PowerPoint Use in this way can be considered as unproductive and that the pedagogical goals may not be achieved. This study has also revealed that the classical way of teaching using board is appreciated by the participants and the results show that pedagogical features such as concentration, grasping and motivation are higher compared to the use of PowerPoint.

Finally, we conclude that PowerPoint use in teaching is not to be fully rejected or abandoned by teachers and lecturers but rather to be well used in a balanced way with classical ways of teaching such as the board. PowerPoint should be used to illustrate concepts and ideas that are difficult to clarify and explain using the board. PowerPoint should be used in manner that keeps the learners motivated and eager for learning. It should be used in a way that guarantees learners' concentration and grasping so that pedagogical goals can be achieved.

As for the perspectives, this study needs to be extended to cover the teachers and lecturers to find out their motivation from using PowerPoint and how they prepare their presentation. The future studies should focus on how to guide teachers and lecturers to well use technology in education without affecting pedagogical features such as concentration, grasping and motivation.

\section{REFERENCES}

Catahan, M. D. (2015). Enhancing Competency of Teachers: A Teaching-And-Learning Enhancement Guide. Bloomington: AuthorHouse. (in English)

Davis, B. G. (2009). Tools for teaching. John Wiley \& Sons. (in English) 
Finkelstein, E., \& Samsonov, P. (2007). PowerPoint for Teachers: Dynamic Presentations and Interactive Classroom Projects (Grades K-12). John Wiley \& Sons. (in English)

Howells, K. (2007). PowerPoint: Friend or Foe? In J. Sigafoos, V. A. Green (Eds.), Technology and teaching (pp. 137-146). New York: Nova Science Publishers. (in English)

Khirwadkar, A., \& Pushpanadham, K. (2005). Information and communication technology in

Ukr. J. of Educ. Stud. and Inf.

Technol.

2020, 8(1) education: interactive multi-media instructional strategies for teaching-learning process. NewDelhi: Sarup \& Sons. (in English)

Livers, A. F. (2008). Using Microsoft Office to enhance student learning. Thousand Oaks: Corwin Press. (in English)

Mortiboys, A. (2010). How to be an effective teacher in higher education: answers to lecturers' questions. McGraw-Hill Education. (in English)

About the author:

Fethi Guerid, Annaba Higher School of Management Sciences, Annaba, Algeria. ORCID: http://orcid.org/0000-0002-5311-9895. gueridfethi@yahoo.fr 